УДК 347.724:347.9(477)

DOI https://doi.org/10.32849/2663-5313/2020.4.08

Максим Суханов,

асистент кафедри інтелектуальної власності,

інформаційного та корпоративного права

юридичного факультету

Львівського національного університету імені Івана Франка

\title{
ХАРАКТЕРИСТИКА ПІДСТАВ НАБУТТЯ КОРПОРАТИВНИХ ПРАВ ТА ОБОВ' ЯЗКІВ УЧАСНИКА ТОВАРИСТВА 3 ОБМЕЖЕНОЮ ВІДПОВІДАЛЬНІСТЮ В ПОРЯДКУ ПРАВОНАСТУПНИЦТВА
}

Стаття присвячена дослідженню підстав набуття корпоративних прав та обов'язків учасників товариства з обмеженою відповідальністю в порядку правонаступництва, які недостатньо конкре тизовані в чинному законодавстві. Констатовано, що набуття корпоративних прав та обов'язків учасника товариства з обмеженою відповідальністю в порядку правонаступництва можливо двома шляхами: в порядку спадкування або в порядку реорганізачії товариства з обмеженою відповідальністю. Наголошено, що ключова проблема визначення підстав набуття корпоративних прав та обов'язків учасників товариства з обмеженою відповідальністю в порядку правонаступничтва обумовлена недостатньою визначеністю в чинному законодавстві прочесу реорганізаиії юридичних осіб корпоративного типу й відсутністю наукових досліджень порушеного питання. Аргументовано, що, зважаючи на залежність частки в статутному капіталі від вкладу учасника в товариство, розмір статутного капіталу товариства з обмеженою відповідальністю, створеного в порядку реорганізащії, дорівнюється розміру власного капіталу товариства, який зафіксований у передавальному акті або розподільчому балансі. На основі проведеного дослідження зроблено висновок, що підставою набуття корпоративних прав та обов'язків учасника товариства з обмеженою відповідальністю в порядку спадкування є внесення державним реєстратором змін до відомостей про юридичну особу, що містяться в Єдиному державному реєстрі юридичних осіб, фізичних осіб - підприємиів та громадських формувань, що передбачають включення спадкодавия до складу учасників товариства з обмеженою відповідальністю. Аргументовано, що підставою для набуття корпоративних прав та обов'язків учасника товариства з обмеженою відповідальністю в порядку реорганізачії юридичної особи корпоративного типу є наявність таких юридичних фактів: а) державної реєстрації в ЄӘиному державному реєстрі юридичних осіб, фізичних осіб - підприємиів та громадських формувань створеного в результаті реорганізації товариства з обмеженою відповідальністю; б) підписання передавального акту (у разі злиття, приєднання або перетворення) або розподільчого балансу (у разі поділу); в ) підписання рішення про створення товариства з обмеженою відповідальністю.

Ключові слова: корпоративні права, спадкування, реорганізація, учасник, товариство 3 обмеженою відповідальністю, підстави, юридична особа корпоративного типу.

Постановка проблеми. На сучасному етапі розвитку сфери господарювання товариство з обмеженою відповідальністю (далі - ТОВ) залишається найбільш привабливою організаційно-правовою формою ведення підприємницької діяльності. Разом із тим у правозастосовній практиці вже тривалий час виникають спірні питання щодо регламентації значної кількості важливих аспектів функціонування ТОВ, які в майбутньому породжують корпоративні конфлікти. Одним із таких питань є визна- чення підстав набуття корпоративних прав та обов'язків учасників ТОВ в порядку правонаступництва.

Правова основа набуття корпоративних прав та обов'язків учасника ТОВ представлена положеннями Закону України «Про товариства $з$ обмеженою та додатковою відповідальністю) від 6 лютого 2018 р. № 2275 (далі - Закон про товариства) [1], Цивільним кодексом України (далі - ЦК України) [2], Законом України «Про державну реєстрацію юридичних осіб, фізичних 
осіб - підприємців та громадських формувань» від 15 травня 2003 р. № 755 (далі Закон про реєстрацію) [3], Господарським кодексом України (далі - ГК України) [4]. Відповідні положення законодавства не позбавлені неточностей і прогалин, які потребують усунення чи конкретизації. Зазначене стосується, зокрема, визначеності щодо набуття прав та обов'язків учасника ТОВ в порядку правонаступництва, формування статутного капіталу ТОВ в порядку реорганізації тощо.

У науці окремі аспекти, що пов'язані із підставами набуття корпоративних прав та обов'язків учасника ТОВ неодноразово досліджували представники науки різних галузей права, зокрема Н.С. Бутрин, В.М. Кравчук, О.М. Вінник, О.А. Воловик, I.Б. Саракун, О.Р. Кібенко, Е.І. Голодницький та інші, проте в їхніх роботах питання уточнення підстав набуття корпоративних прав та обов'язків учасника ТОВ в порядку правонаступництва розглядались або опосередковано, або взагалі не розглядались. Певна частина досліджень проведена до оновлення законодавства про ТОВ. Наведене вказує на актуальність і доцільність наукового дослідження за обраною темою.

Метою статті є обгрунтування пропозицій щодо підстав набуття корпоративних прав та обов'язків учасників ТОВ у порядку правонаступництва.

Виклад основного матеріалу. Набуття корпоративних прав та обов'язків учасника ТОВ в порядку правонаступництва можливо двома шляхами: в порядку спадкування або в порядку реорганізації юридичної особи корпоративного типу.

В порядку спадкування набуття корпоративних прав та обов'язків учасника ТОВ є можливим тільки у випадку, якщо спадкодавець володів корпоративними правами цього виду юридичної особи корпоративного типу та має спадкоємців або залишив заповіт.

Для формулювання підстави набуття окреслених прав та обов'язків спадкоємцями звернемося до відповідного порядку. Системний аналіз ст. 3 Закону про товариства та ст. ЦК України, ч. 5 ст. 17 Закону про реєстрацію дає право виділити такі його етапи: 1) прийняття спадкоємцем спадщини й одержання свідоцтва про право на спадщину; 2) звернення до державного реєстратора з заявою про державну реєстрацію змін до відомостей про юридичну особу, що містяться в Єдиному державному реєстрі юридичних осіб, фізичних осіб - підприємців та громадських формувань; разом із такою заявою державному реєстратору подається заява про вступ до ТОВ, нотаріально засвідчена копія свідоцтва про право на спадщину, документ про сплату адміністративного збору; 3) державна реєстрація змін до відомостей про юридичну особу, що містяться в Єдиному державному реєстрі юридичних осіб, фізичних осіб - підприємців та громадських формувань. Проведення реєстраційних дій відбувається впродовж 24 годин після надходження документів до державного реєстратора, крім вихідних і святкових днів.

Варто відзначити, що перехід частки спадкодавця до його спадкоємців не вимагає отримання згоди учасників товариства (ч. 1 ст. 23 Закону про товариства) та внесення змін до статуту товариства (ч. 5 ст. 11 Закону про товариства). Отже, зміна складу учасників у такому випадку не оформлюється рішенням загальних зборів ТОВ. Підхід законодавця до врегулювання порушеного питання заслуговує підтримки, адже М. Ліхачова та О. Пиголь слушно відзначають, що окреслені правила «значно спрощують життя спадкоємців часток і не дають змогу несумлінним учасникам товариства перешкодити правонаступнику в повному обсязі скористатися своїми правами на управління» [5]. ТОВ та інші учасники товариства, як правило, дізнаються про зміну складу його учасників із листа державного реєстратора, який містить виписку з Сдиного державного реєстру юридичних осіб, фізичних осіб - підприємців та громадських формувань і надсилається таким особам у день проведення державної реєстрації відповідних змін поштовим відправленням з описом вкладення на відому електронну пошту таких осіб (ч. 4 ст. 24 Закону про реєстрацію).

Необхідно також звернути увагу, що натепер на законодавчому рівні не уточнено момент, з якого особа набуває правового статусу учасника ТOB, зміст якого охоплює права та обов'язки. Поряд із цим, ч. 5 ст. 4 Закону про товариства чітко визначено момент виходу учасника з товариства, зокрема учасник вважається таким, що вийшов 3 товариства, з дня державної реєстрації його виходу. Навіть більше, відповідно до ч. 1 ст. 10 Закону про реєстрацію, якщо відомості, що підлягають внесенню до Єдиного державного реєстру, внесені до нього, такі відомості вважаються достовірними й можуть бути використані в спорі 3 третьою особою.

Враховуючи викладене, набуття статусу учасника товариства, а отже його прав та обов'язків учасника TOB, залежить від моменту державної реєстрації його входу до складу учасників ТОВ. 
Уточнення підстав набуття корпоративних прав та обов'язків учасника ТОВ у процесі реорганізації є дещо складнішим з огляду на недостатню визначеність у чинному законодавстві відповідного процесу й відсутність наукових досліджень порушеного питання. Зокрема, юридична особа корпоративного типу може бути реорганізована в ТОВ шляхом злиття, приєднання, поділу, перетворення (ч. 1 ст. 104 ЦК України). Разом із тим, у ТОВ можуть бути реорганізовані тільки юридичні особи корпоративного типу. Зважаючи на те, що останнім етапом реорганізації завжди є створення в результаті її проведення нової юридичної особи, можна допустити, що підстави набуття корпоративних прав та обов'язків учасника ТОВ мають бути тотожні підставам, що мають місце у випадку заснування ТОВ. Однак таке припущення не зможе стати грунтовною основою для уточнення підстав набуття корпоративних прав та обов'язків учасника ТОВ у процесі реорганізації з огляду на деякі чинники.

По-перше, в юридичній науці досі ведуться дискусії щодо підстав набуття корпоративних прав та обов'язків учасника первинним способом - шляхом заснування нового товариства. Водночас часто в дослідженнях, присвячених корпоративним правам та обов'язкам це питання залишається поза увагою науковців. Так, Я.С. Марущак вважає, що «внаслідок реалізації права на заснування юридичної особи корпоративного типу і внесення вкладу до статутного (складеного) капіталу особа-засновник (далі - учасник) набуває низку майнових і немайнових прав, пов'язаних з діяльністю й управлінням цією юридичною особою» [6, с. 78.] Зважаючи на те, що право на заснування юридичної особи корпоративного типу можна вважати реалізованим із моменту реального заснування такої особи, тобто іï державної реєстрації, то підставами для набуття корпоративних прав та обов'язків учений вважає державну реєстрацію товариства і внесення вкладу до статутного капіталу.

А. Сороченко підставами виникнення в особи корпоративних прав вважає наявність зареєстрованого в установленому законодавством порядку товариства й наявність частки особи в статутному капіталі такої організації [7, с. 85]. Таке формулювання обумовлює виникнення питання про те, що саме вчений має на увазі, говорячи про наявність частки, її виділення в певному розмірі рішенням засновників або її оплату.

Разом із тим, одностайною є позиція вчених про залежність виникнення корпоративних прав та обов’язків учасника від державної реєстрації юридичної особи корпоративного типу. Підтримуючи науковців у цій частині, варто навести тезу Г. Смірнова про те, що корпоративні відносини можуть існувати до створення юридичної особи, але корпоративні права на цьому етапі виникнути не можуть, тому що корпоративні права виникають тільки після створення юридичної особи корпоративного типу [8, c. 61].

На наш погляд вирішальне значення для набуття корпоративних прав та обов'язків перші шість місяців має виділення учаснику частки в певному розмірі рішенням засновників, оскільки системний аналіз ст. ст. 14, 15, 29 Закону про товариства дає підстави дійти висновку, що до спливу строку оплати частки право голосу учасника на загальних зборах не обмежується. Навіть більше, у ст. 167 ГК України корпоративне право пов'язане з часткою, яка визначена у статутному капіталі (не сплачена $-M$. $C$.). Такий підхід законодавця є дискусійним, адже А.В. Смітюх слушно зауважує, що корпоративні права може мати тільки власник частки, оскільки корпоративні права йдуть за часткою [9, с. 92]. Між тим, ненадання особам, які не зробили свій вклад до статутного капіталу з причини наявності в них на це шестимісячного строку, права брати участь у загальних зборах товариства може стати перешкодою для прийняття певних рішень. Отже, в цьому випадку слід міркувати про доцільність закріплення в Законі про товариства такого порядку формування статутного капіталу, що не охоплюється метою цього дослідження.

По-друге, такий висновок може бути передчасним з огляду на відмінність формування статутного капіталу у вперше заснованого ТОВ і TOB, яке створене в результаті реорганізації, оскільки корпоративні права й обов'язки пов'язані з часткою в статутному капіталі ТОВ.

Так, до правонаступника мають перейти майно, права та обов'язки реорганізованої юридичної особи (ч. 1 ст. 48 Закону про товариства). 3 огляду на вказане, відповідь на питання про підстави набуття корпоративних прав та обов'язків учасника ТОВ у процесі реорганізації прямо залежить від таких складових цього процесу, як формування статутного капіталу новоствореного ТОВ Чинне законодавство не містить відповідних положень.

Важливі аспекти формування статутного капіталу новоствореного ТОВ відображаються в рішенні вищого органу управління юридичної особи корпоративного типу про його реорганізацію певним способом. Зокрема, приймаючи рішення про реорганізацію, 
учасники/акціонери мають одразу визначити умови й порядок конвертації (обміну) часток у статутному капіталі на частки ТОВ що створюються шляхом реорганізації тощо. Водночас товариства, які беруть участь у припиненні, наділені правом укласти договір про припинення, в якому мають бути визначені «умови передачі майна, прав та обов'язків юридичним особам - правонаступникам, розмір часток кожного учасника в статутному капіталі кожної юридичної особи - правонаступника або коефіцієнти конвертації часток в акції (якщо правонаступниками є акціонерні товариства), склад органів юридичних осіб - правонаступників та інші умови припинення» (ст. 53 Закону про товариства). Звісно, умови такого договору мають відповідати правилам конвертації часток, які регламентовані ст. 54 Закону про товариства й ст. 80 Закону України «Про акціонерні товариства» [10].

Далі набуває значення передавальний акт (у разі злиття, приєднання або перетворення) або розподільчий баланс (у разі поділу) юридичної особи корпоративного типу, що реорганізується. Доводиться констатувати, що вимоги до змісту такого документу регламентовані чинним законодавством достатньо повільно, адже у ч. 2 ст. 107 ЦК України є вказівка на необхідність відображення у передавальному акті або розподільчому балансі інформації про правонаступництво щодо майна, прав та обов'язків юридичної особи, що припиняється шляхом поділу, стосовно всіх їі кредиторів і боржників, включаючи зобов'язання, які оспорюються сторонами. По суті, у згаданих актах має відображатися інформація про весь капітал, який залишився після проведення розрахунків із кредиторами. Зважаючи на залежність частки в статутному капіталі від вкладу учасника в товариство, логічно констатувати, що розмір статутного капіталу має дорівнюватися розміру власного капіталу товариства, який відображений у передавальному акті або розподільчому балансі. Додатковим аргументом на користь цього висновку є позиція Держпідприємництва, яка викладена в Листі «Про формування статутного фонду ТОВ, створеного шляхом реорганізації» від 13 жовтня 2009 р. № 12368, та полягає в тому, що розмір статутного фонду (капіталу) суб'єкта господарювання, створеного в результаті реорганізації шляхом перетворення, може бути підтверджений передавальним балансом [11].

Навіть більше, якщо у випадку державної реєстрації новоствореного товариства державному реєстратору треба надати документи на підтвердження внесення засновниками грошових сум на банківський рахунок або передачу у власність ТОВ певного майна, цінних паперів, то у випадку державної реєстрації товариства в порядку реорганізації державному реєстратору подається примірник оригіналу або нотаріально засвідчена копія передавального акту або розподільчого балансу (у разі створення юридичної особи в результаті поділу або виділу).

Викладене дає право зробити висновок, що у випадку створення ТОВ в процесі реорганізації статутний капітал не формується, адже $є$ сформованим його попередником. Отже, частки в статутному капіталі учасниками вже оплачені. До того ж, як уже було зазначено, їхній розмір визначається у рішенні учасників/акціонерів про реорганізацію. Як правило, учасниками ТОВ, створеного в процесі реорганізації, є особи, які володіють корпоративними правами юридичних осіб-правопопередників.

Досліджуючи це питання, В. Кулаков без наведення жодних аргументів висловлює думку, що в момент підписання передавального балансу або розподільчого акту до новоствореного товариства переходять майно, права й обов'язки реорганізованої юридичної особи (осіб) [11, с. 6].

Вважаємо конструктивнішим стверджувати, що в момент підписання цих актів визнається розмір статутного капіталу новоствореного товариства, адже передавальний баланс або розподільчий акт підписуються до моменту його державної реєстрації. Тому підписання вищевказаних документів не може бути єдиною підставою для набуття корпоративних прав та обов'язків ТОВ, створеного в порядку реорганізації.

Варто відзначити, що в законодавстві визначено момент завершення реорганізації. Наприклад, поділ є завершеним 3 дати державної реєстрації припинення юридичної особи, яка припиняється в результаті поділу (ст. 4 Закону про реєстрацію) [3]; злиття, поділ або перетворення акціонерного товариства є завершеними з дати внесення до Єдиного державного реєстру запису про припинення акціонерного товариства та про реєстрацію підприємницького товариства-правонаступника (товариств-правонаступників) (ч. 6 ст. 80 Закону України «Акціонерні товариства») [10]. Наведене обумовлює виникнення питання про вплив моменту закінчення реорганізації на набуття корпоративних прав та обов'язків учасником новоствореного ТОВ. Звісно, такий вплив $€$.

У зв'язку з цим набуває значення думка Г. Смірнова про те, що до моменту створення юридичної особи учасники не набувають корпоративних прав навіть у випадку сплати часток до статутного капіталу товариства 
або розміщення акцій [8, с. 60]. Правильність такого судження не потребує доведення, проте вимагає уточнення відносно об'єкту дослідження. Зокрема, закінчення реорганізації юридичної особи корпоративного типу означає припинення корпоративних прав iï учасників і виникнення їх у товариства (товариств), створеного (створених) в процесі реорганізації.

Таким чином, підстави набуття корпоративних прав та обов'язків учасника ТОВ, що створено в процесі реорганізації, залежать від рішення учасників юридичної особи корпоративного типу, яка реорганізується, та припинення іiі діяльності, підписання передавального акту або розпорядчого балансу й державної реєстрації новоствореного ТОВ.

\section{Висновки}

Підсумовуючи все вищевикладене, можна зробити такі висновки: 1) спадкування корпоративних прав i реорганізація юридичної особи корпоративного типу обумовлюють набуття корпоративних прав та обов'язків учасника ТОВ в порядку правонаступництва; 2) підставою набуття корпоративних прав та обов'язків учасника ТОВ в порядку спадкування $є$ внесення державним реєстратором змін до відомостей про юридичну особу, що містяться в Єдиному державному реєстрі юридичних осіб, фізичних осіб - підприємців та громадських формувань, що передбачають включення спадкодавця до складу учасників ТОВ; 3) підстави набуття корпоративних прав та обов'язків учасника ТОВ в порядку реорганізації юридичної особи корпоративного типу передбачають одночасну наявність таких юридичних фактів: а) підписання рішення про реорганізацію юридичної особи корпоративного типу, в якому відображається розмір частки (часток) учасників ТОВ, яка (які) створена (створені) в результаті реорганізації; б) підписання передавального акту (в разі злиття, приєднання або перетворення) або розподільчого балансу (в разі поділу); в) державна реєстрація в Єдиному державному реєстрі юридичних осіб, фізичних осіб - підприємців та громадських формувань створеного (створених) в результаті реорганізації ТОВ.

Вивчення особливостей визначення розміру часток учасників ТОВ у статутному капіталі ТОВ, утвореного в процесі реорганізації, має стати предметом подальших наукових досліджень.

\section{Список використаних джерел:}

1. Про товариства з обмеженою та додатковою відповідальністю : Закон України від 6 лютого 2018 р. № 2275-VIII. Відомості Верховної Ради України. 2018. № 13. Ст. 69.

2. Цивільний кодекс України : Закон України від 16 січня 2003 р. № 435. Відомості Верховної Ради України. 2003. № № 40-44. Ст. 356.

3. Про державну реєстрацію юридичних осіб, фізичних осіб - підприємців та громадських формувань : Закон України від 15 травня 2003 р. № 755-IV (в редакції від 26 листопада 2015 р.). Відомості Верховної Ради України. 2016. № 2. Ст. 17.

4. Господарський кодекс України : Закон України від 16 січня 2003 р. № 436. Відомості Верховної Ради України. 2003. № № 18-22. Ст. 144

5. Ліхачев М., Пиголь О. Як успадкувати частку в TOB за новим законом? URL: https:// yur-gazeta.com/publications/practice/korporativnepravo-ma/yak-uspadkuvati-chastku-v-tov-za-novimzakonom.html (дата звернення: 27.03.2020).

6. Марущак Я.С. Корпоративні права та обов'язки за законодавством України та Європейського Союзу : дис. ... канд. юрид. наук : 12.00 .03 Нац. універ. «Одеська юридична академія». Одеса, 2018. $224 \mathrm{c}$.

7. Сороченко А. Підстави набуття корпоративних прав та момент виникнення корпоративних правовідносин за законодавством України. Вісник Київського наиіонального університету імені Тараса Шевченка. 2012. № 94. С. 83-86.

8. Смірнов Г. Корпоративні права: поняття та правова природа. Підприємниитво, господарство $i$ право. 2020. № 2. С. 59-67.

9. Смітюх А.В. Щодо правової природи частки у статутному капіталі господарського товариства. Правова держава. 2015. № 19. С. 89-94.

10. Про акціонерні товариства : Закон України від 19 вересня 2008 р. № 514. Відомості Верховної Ради України. 2008. № № 50-51. Ст. 384.

11. Про формування статутного фонду ТОВ створеного шляхом реорганізації : лист Державного комітету України з питань регуляторної політики та підприємництва від 13 жовтня 2009 р. № 12368. URL: http://search.ligazakon.ua/ 1_doc2.nsf/link1/DP2639.html (дата звернення: 27.03.2020).

12. Кулаков В. Окремі питання проведення реорганізації товариства $з$ обмеженою відповідальністю. Підприємниитво, господарство і право. 2019. № 7. C. 5-9.

The article is devoted to the study of the grounds of acquiring the corporate rights and obligations of the limited liability company members in the order of legal succession, which are not fully specified in the current legislation. It is stated that the acquisition of corporate rights and obligations of a limited liability company member in legal succession is possible in two ways: in the order of inheritance or in order of reorganization of a limited liability company. 
It is emphasized that the key problem is to determine the grounds for acquiring the of corporate rights and obligations of the limited liability company members in the order of succession is due to the lack of certainty in the current legislation of the process of corporate reorganization of corporate entities and to the lack of scientific research on the issue. It is shown that taking into consideration the dependence of the capital share on the participant's contribution to the company, the capital share of the limited liability company which was created in the reorganization order is equal to the size of the company's equity, which is reflected in the act of transfer or distribution balance sheet. On the basis of the conducted research the conclusion is made that the basis of acquisition of corporate rights and obligations of a limited liability company member in the order of inheritance is the introduction by the state registrar of changes to the information on the legal entity contained in the Unified State Register of Legal Entities, Individual Entrepreneurs and Public Organizations that provide for the inclusion of the heir to the members of the limited liability company. It is argued that the basis for acquiring the corporate rights and obligations of a member of a limited liability company in order to reorganize a corporate entity is the presence of the following legal facts: a) state registration in the Unified State Register of Legal Entities, Individual Entrepreneurs and Public Organizations of the limited liability company created due to reorganization; $b$ ) signing of the act of transfer (in the case of merger, accession or transformation) or the balance sheet (in the case of division); c) signing of the decision on creation of the limited liability company.

Key words: corporate rights, inheritance, reorganization, member, limited liability company, grounds, corporate body. 